Brit. J. industr. Med., 1964, 21, 124.

\title{
A STUDY OF BYSSINOSIS, CHRONIC RESPIRATORY SYMPTOMS, AND VENTILATORY CAPACITY IN ENGLISH AND DUTCH COTTON WORKERS, WITH SPECIAL REFERENCE TO ATMOSPHERIC POLLUTION
}

\author{
BY
}

\author{
B. LAMMERS, R. S. F. SCHILLING, and JOAN WALFORD \\ WITH
}

\begin{abstract}
SUSAN MEADOWS, S. A. ROACH, D. VAN DEN HOVEN VAN GENDEREN, Y. G. VAN DER VEEN, and C. H. WOOD

From the London School of Hygiene and Tropical Medicine, and the Almelo Industrial Medical Service, the Netherlands
\end{abstract}

(RECEIVED FOR PUBLICATION NOVEMBER 23, 1963)

An epidemiological survey of 414 English and 980 Dutch male cotton workers was undertaken to determine the prevalence of byssinosis and respiratory symptoms, and to compare the ventilatory capacities in the two populations, with particular reference to the influence of air pollution. The English workers were employed in six mills in Lancashire and the Dutch workers in three mills in Almelo spinning similar grades of cotton.

The methods used included a questionnaire on respiratory symptoms and illnesses, the collection and examination of sputum, and the measurement of the forced expiratory volume over $0.75 \mathrm{sec}$. Concentrations of smoke and sulphur dioxide were measured in the English and Dutch towns.

The crude rates for byssinosis were similar, $13.5 \%$ and $17 \%$ respectively in the English and Dutch card and blow rooms, and $1.5 \%$ and $1.6 \%$ respectively in the spinning rooms. The English workers had significantly higher prevalences of persistent cough and persistent phlegm and significantly lower indirect maximum breathing capacities. These findings were supported by the results of a sputum survey. Nearly twice as many English produced specimens, and the mean volume of sputum was greater for the English workers.

The prevalence of bronchitis, defined as persistent phlegm and at least one chest illness during the past three years, causing absence from work, was higher in the English than in the Dutch workers in both types of work room, but not significantly so after standardizing for differences in age. Since there are important differences in the social security systems of the two countries, which may encourage more absence from illness among the Dutch, a comparison of bronchitis thus defined is likely to be invalid.

The higher prevalences of respiratory symptoms and lower ventilatory capacities in the English are unlikely to be due to observer error. They are discussed in relation to smoking habits, exposure to cotton dust, and air pollution. The most likely explanation of the unfavourable picture presented by the English workers is the much higher level of air pollution in Lancashire.

For many years England has been the only country with reliable evidence of the extent and severity of byssinosis among cotton workers. Recent surveys have now revealed that cotton workers in the Netherlands, India, Egypt, and the United States have the characteristic symptoms of byssinosis, namely, chest tightness on returning to work after the week-end break (British Medical Journal, 1962; Muller, Vismans, and van Blommestein, 1962). However, the methods of survey in the different countries have not been sufficiently alike to enable valid comparisons to be made between them or to 
show whether or not the workers in these countries are as severely affected as those in England.

Apart from those in Egypt, the English cotton operatives are the only workers for whom there is a compensation scheme for byssinosis. The Egyptian scheme was started in 1961 and no awards have yet been made. The British scheme has been in force since 1941 and about 400 pensions are now awarded annually for new cases of byssinosis out of some 12,000 workers at risk and eligible for compensation. It is these figures, and the absence of any comparable data from other countries, that have been largely responsible for the belief that byssinosis presents a serious problem in England alone, and that the occurrence of the disease is influenced by factors additional to cotton dust exposure and specific to England.

In England the cotton industry is concentrated in and around the south-east Lancashire conurbation where adverse environmental factors, especially air pollution, are believed to be responsible for the high incidence of chronic bronchitis in the area (Goodman, Lane, and Rampling, 1953; Reid, 1956). Since the later stages of byssinosis are often similar to those of chronic bronchitis it is not surprising that the polluted atmosphere of the mill towns has been suggested as a vital factor in producing disabling byssinosis (British Medical Journal, 1962).

It was decided, therefore, to undertake a comparative epidemiological study of byssinosis and other respiratory symptoms in England and some other country with a similar climate but cleaner air. If air pollution plays a major role in the aetiology of byssinosis as well as chronic bronchitis, the Lancashire cotton workers would be expected to have a higher prevalence and severity of both diseases.

\section{Choice of Country and Mills}

The Netherlands was chosen for two main reasons. First, while conditions in the English and Dutch mills were sufficiently alike to permit valid occupational comparisons, the Dutch towns in which the mills are situated appeared to have much less atmospheric pollution than the English mill towns. Secondly, the two countries were close enough to permit frequent discussion of the many problems which would arise in a comparative study of this nature.

Much of the Dutch cotton industry is concentrated in the region of Twenthe near the German border. In the west of Twenthe lies the town of Almelo with a population of about 50,000. The visitor from England is struck by the clean exterior of its buildings, the open countryside around the town, and the apparent absence of atmospheric pollution. Almelo is more like a market town in southern England than a Lancashire mill town. It has an interplant occupational health service which caters for 35 factories, including the three mills in which this survey was made (Lammers, 1962). These mills were spinning yarn from medium quality American type cotton with counts ranging from 10's to 130's.* Since both the prevalence and severity of byssinosis is inversely related to the quality of cotton spun (Schilling, 1956) it was necessary to select for comparison English mills spinning within this range of counts.

Six English mills were chosen so as to obtain a sufficient number of men for effective comparison with the Dutch, since all their workers were men whereas English mills employ a large proportion of women. Two of the mills are within the south-east Lancashire conurbation: one is in Swinton and Pendlebury, which has a population of 40,000 , and the other is nearby. Three more lie on the fringe of the conurbation: two in the Bolton area, which has a population of over 160,000, and one in Atherton, a small town with 10,000 inhabitants, lying five miles south-west of Bolton. The remaining mill is in Chorley, with a population of $31,000,12$ miles northwest of Bolton and separated from it by moorland, and lying well outside the south-east Lancashire conurbation.

\section{Populations}

The populations studied consisted of all the male card room, blow room, and spinning room workers in the three Dutch mills and in three of the English mills. In the other three English mills only the card and blow room workers were included. The persons to be seen were defined as those on the factory books on the day the survey of each factory was started. Those who had been continuously absent for the previous two months were excluded. The number seen in each country was over $96 \%$ of the defined population (Table 1). The surveys in both countries were undertaken between 1960 and 1962 .

\section{Methods}

The methods of collecting the data are described under four main headings.

Questionnaire.-Respiratory symptoms, past history of chest diseases, and smoking habits were recorded for each worker, using the standardized questions in a Medical Research Council questionnaire on chronic bronchitis. These questions have been shown to give reasonably consistent assessments of symptoms (Higgins,

* Counts are based on the number of hanks 840 yards $(768 \mathrm{~m}$.) long in $1 \mathrm{lb}$. $(0.45 \mathrm{~kg}$.) of cotton. 
TABLE 1

MALE POPULATION SURVEYED IN SIX ENGLISH AND THREE DUTCH COTTON MILLS

\begin{tabular}{|c|c|c|c|c|}
\hline \multirow[b]{2}{*}{. } & \multirow{2}{*}{$\begin{array}{l}\text { Number } \\
\text { At Risk }\end{array}$} & \multicolumn{3}{|c|}{ Number Seen } \\
\hline & & $\begin{array}{c}\text { Card and } \\
\text { Blow Rooms }\end{array}$ & $\begin{array}{l}\text { Spinning } \\
\text { Rooms }\end{array}$ & Total \\
\hline $\begin{array}{l}\text { English } \\
\text { Dutch }\end{array}$ & $\begin{array}{r}418 \\
1,014\end{array}$ & $\begin{array}{l}202 \\
475\end{array}$ & $\begin{array}{l}212 \\
505\end{array}$ & $\begin{array}{l}414(99.0 \%) \\
980(96.6 \%)\end{array}$ \\
\hline
\end{tabular}

1957; Higgins and Cochran, 1958; Higgins, Cochrane, Gilson, and Wood, 1959; Olsen and Gilson, 1960). The questionnaire was extended to include questions on byssinosis, which was graded as follows: grade $\frac{1}{2}-$ occasional chest tightness on Mondays; grade 1 -chest tightness and/or difficulty in breathing on Mondays only; grade 2 - chest tightness and/or difficulty in breathing on Mondays and other days.

Collection and Examination of Sputum.-Specimens of sputum from a sample of workers in both countries were collected during the summer and examined by the technique described by Elmes, Dutton, and Fletcher (1959). The specimens from the English workers were taken at the time of the survey. The Dutch specimens had to be taken a year after the main survey had been completed. Workers were given an empty bottle and asked to collect in it all the sputum they produced in the first hour after getting up. The volume and macroscopic appearance of the specimens were recorded before they were dispatched for bacteriological examination, which was started approximately seven hours after the specimen had been produced.

Respiratory Function Tests.-The forced expiratory volume over 0.75 second (F.E.V. ${ }_{0.75}$ ) was measured with a spirometer and timer and expressed as indirect maximum breathing capacity (I.M.B.C.) by multiplying the volume by 40 . One set of measurements was taken for every worker during the initial interview. The general procedure was similar to that used and described in previous investigations (McKerrow, McDermott, Gilson, and Schilling, 1958).

Dust Sampling.-The airborne dust in the mills was sampled during the whole eight-hour shift in the areas in which workers were employed to obtain a gravimetric measure of dust concentration. The equipment used was the same as that used in a previous study and is based on the hexhlet (Roach and Schilling, 1960).

\section{Comparative Surveys}

There are special difficulties inherent in any survey of respiratory disease where reliance has to be placed on answers to questions about respiratory symptoms and on tests of lung function which depend on the subject's ability to understand how to do the test and on his willingness to co-operate.

It was realized that these difficulties would be even greater in this study because of the differences in language and the necessity to use one group of four observers for the English workers and another four observers for the Dutch.

One problem was to ensure that the English and Dutch questions on respiratory symptoms and disease were identical in meaning. The original questionnaire was translated into Dutch by two physicians participating in the survey and then back into English by another Dutchman who was not a physician. This version contained five major differences from the original, all of which were corrected in the final questionnaire used in the Netherlands.

To detect differences in interview technique between observers in the two countries a group of 27 English cotton workers, not included in this survey, were examined by one of the Dutch observers. The interviews were tape-recorded and interpreted by one of the English observers. There were no major differences in interview technique. The English observer did diagnose byssinosis (grade $\frac{1}{2}$ ) in two workers regarded as normal by the Dutch observer. This error was most likely due to the Dutch doctor's difficulty in understanding the workers' English and vice versa, since this is the mildest manifestation of byssinosis and therefore the most difficult to diagnose.

In the lung function tests, identical apparatus was used in both countries and repeatedly calibrated during the surveys. Methods of performing the tests were standardized, as far as possible, by instructing all observers to obtain the optimum response from their subjects by ensuring that they inspired fully and kept their lips tightly closed over the mouth-piece during forced expiration.

An attempt was made to find out if there were major differences in the method of conducting the lung function tests. One Dutch and one English observer were chosen to take part in experiments, carried out in England and in Holland, in which each subject was tested by both observers. There were no significant differences between the readings of the two observers, and further comparison of each with his colleagues gave similar results.

There were few difficulties in standardizing the dust sampling. Similar instruments and methods were used in both countries. All the samples were weighed and analysed in England.

The macroscopic assessment of a specimen of sputum and its classification into mucoid, muco-purulent, or purulent is subjective and liable to considerable observer variation. In order to remove bias, one observer (C.H.W.) assessed all the specimens in both countries. Unfortunately, the English and Dutch sputa were not cultured in exactly the same way, the principal difference being that the Dutch specimens were washed before plating, the method used routinely throughout the Netherlands.

\section{Results}

As there were only three Dutch workers over the age of 65 , the results are based on men aged 15 to 64 years. The crude prevalence rate of byssinosis is higher in the Dutch than in the English card and 

FIG. 1.- Standardized ratios for in English and Dutch cotton workers.
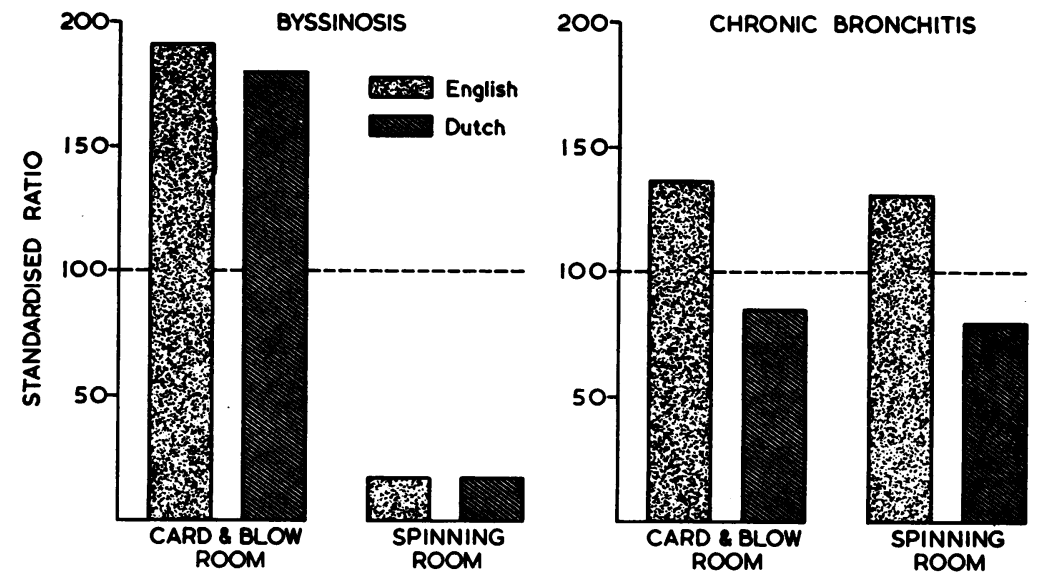

blow rooms* but similar in the spinning rooms. The prevalence of chronic bronchitis, defined as persistent sputum and at least one chest illness involving absence from work for more than one week in the previous three years, is higher among the English than the Dutch workers in both kinds of work rooms. Since the crude rates are affected by differences in the age distribution of the populations further comparisons have been made by using standardized ratios (Table 2; Fig. 1). These were

\section{TABLE 2}

CRUDE RATES AND AGE STANDARDIZED RATIOS FOR BYSSINOSIS AND CHRONIC BRONCHITIS* IN ENGLISH AND DUTCH MALE COTTON WORKERS AGED 15-64 YEARS

\begin{tabular}{|c|c|c|c|c|}
\hline \multirow{2}{*}{ Group } & \multicolumn{2}{|c|}{ Crude Rates (\%) } & \multicolumn{2}{|c|}{$\begin{array}{l}\text { Standardized Ratios } \\
\text { (all cotton workers } \\
=100)\end{array}$} \\
\hline & Byssinosis & $\begin{array}{l}\text { Chronic* } \\
\text { Bronchitis }\end{array}$ & Byssinosis & $\begin{array}{l}\text { Chronic * } \\
\text { Bronchitis }\end{array}$ \\
\hline $\begin{array}{l}\text { Card and Blow Room } \\
\text { English } \\
\text { Dutch } \\
\text { Spinning Room }\end{array}$ & $\begin{array}{l}13.5 \\
17.0\end{array}$ & $\begin{array}{l}6 \cdot 8 \\
4 \cdot 0\end{array}$ & $\begin{array}{l}194 \\
180\end{array}$ & $\begin{array}{r}138 \\
85\end{array}$ \\
\hline $\begin{array}{l}\text { English } \\
\text { Dutch }\end{array}$ & $\begin{array}{l}1.5 \\
1.6\end{array}$ & $\begin{array}{l}8 \cdot 2 \\
3 \cdot 2\end{array}$ & $\begin{array}{l}18 \\
18\end{array}$ & $\begin{array}{r}132 \\
81\end{array}$ \\
\hline
\end{tabular}

*Defined as those with persistent phlegm and at least one chest illness causing absence from work for at least seven days in the last three years.

obtained by expressing the observed number of cases as a percentage of the number of cases that would be 'expected'. The 'expected' number of cases was derived by calculating the prevalence rates for each 10-year age group of the combined English and Dutch populations and applying them by simple proportion to the population at ages of the separate groups.

* As there are very few blow room workers, and their dust exposure is similar to that of card room workers, the card and blow room populations have been combined for the purpose of analysis.
Byssinosis.-As expected from previous studies (Schilling, 1956), the risk is very much higher in the card and blow rooms than in the spinning rooms. After standardization for age there is little difference in the prevalence of byssinosis for the comparable groups of English and Dutch workers. Nevertheless, the pattern of severity is quite different, with the Dutch having more of their byssinotics in the highest and lowest grades (Table 3). With proportionately three times as many byssinotics in grade 2 it might be reasoned that the Dutch were more disabled than the English. Evidence from the ventilatory capacity

TABLE 3

BYSSINOSIS IN 28 ENGLISH AND 85 DUTCH MALE COTTON WORKERS AGED 15-64 YEARS

\begin{tabular}{|c|c|c|}
\hline Byssinosis Grade & English & Dutch \\
\hline $\begin{array}{l}\frac{1}{2} \\
1 \\
2\end{array}$ & $\begin{aligned} 4 & (14 \%) \\
21 & (75 \%) \\
3 & (11 \%)\end{aligned}$ & $\begin{array}{ll}24 & (28 \%) \\
30 & (35 \%) \\
31 & (37 \%)\end{array}$ \\
\hline Total & $28(100 \%)$ & $85(100 \%)$ \\
\hline
\end{tabular}

tests (see page 128) and indices of effort intolerance failed to support this suggestion. It is possible that the Dutch observers had different standards of interpretation and that their workers were able to distinguish the symptoms of byssinosis more easily than the English because they were less affected by other respiratory disease.

Bronchitis and Other Chest Symptoms.-The prevalence of chronic bronchitis as defined in this paper is higher among the English than the Dutch, but not significantly so. When the two components of bronchitis-recent chest illness and persistent phlegm - are examined separately, significantly more English workers complain of persistent phlegm 
TABLE 4

CHEST SYMPTOMS STANDARDIZED FOR AGE AND EXPRESSED AS STANDARDIZED RATIOS (ALL COTTON WORKERS $=100)$

\begin{tabular}{|c|c|c|c|c|c|c|}
\hline \multirow{2}{*}{ Chest Symptoms } & \multicolumn{3}{|c|}{ Card and Blow Rooms } & \multicolumn{3}{|c|}{ Spinning Rooms } \\
\hline & English & Dutch & $\mathbf{P}$ & English & Dutch & $\mathbf{P}$ \\
\hline $\begin{array}{l}\text { Bronchitis components:- } \\
\text { Persistent phlegm } \\
\text { Recent chest iliness } \\
\text { Persistent cough } \\
\text { Wheezing } \\
\text { Chest affected by weather }\end{array}$ & $\begin{array}{l}171 \\
138 \\
171 \\
132 \\
121\end{array}$ & $\begin{array}{r}86 \\
107 \\
96 \\
99 \\
104\end{array}$ & $\begin{array}{l}0.0003 \\
\text { N.S. } \\
0.001 \\
0.04 \\
\text { N.S. }\end{array}$ & $\begin{array}{r}129 \\
115 \\
109 \\
112 \\
97\end{array}$ & $\begin{array}{l}69 \\
70 \\
69 \\
83 \\
89\end{array}$ & $\begin{array}{c}0.002 \\
\text { N.S. } \\
0.02 \\
0.03 \\
\text { N.S. }\end{array}$ \\
\hline
\end{tabular}

TABLE 5

MACROSCOPIC ANALYSIS OF ENGLISH AND DUTCH SPECIMENS OF SPUTUM

\begin{tabular}{|c|c|c|c|c|c|c|}
\hline & \multirow{2}{*}{$\begin{array}{l}\text { No. of Workers } \\
\text { in Sample }\end{array}$} & \multirow{2}{*}{$\begin{array}{l}\text { No. Producing } \\
\text { Specimen }\end{array}$} & \multirow{2}{*}{$\begin{array}{l}\text { Mean Volume } \\
\text { of Specimen } \\
\text { (ml.) }\end{array}$} & \multicolumn{3}{|c|}{ Macroscopic Appearance (\%)* } \\
\hline & & & & Mucoid & Muco-purulent & Purulent \\
\hline $\begin{array}{l}\text { English } \\
\text { Dutch }\end{array}$ & $\begin{array}{l}286 \\
288\end{array}$ & $\begin{array}{l}96(36 \%) \\
51(19 \%)\end{array}$ & $\begin{array}{l}2 \cdot 8 \\
2 \cdot 4\end{array}$ & $\begin{array}{l}76 \\
85\end{array}$ & $\begin{array}{l}21 \\
15\end{array}$ & $\stackrel{3}{-}$ \\
\hline
\end{tabular}

- Percentages apply to specimens, not total population.

Haemophilus influenzae was cultured from $21 \%$ of the English and $12 \%$ of the Dutch specimens.

(Table 4). More English than Dutch workers reported a recent chest illness, but the excess is not significant. There are, however, important differences in the social security systems of the two countries which may encourage more absence from illness among the Dutch; they get almost full pay when off sick, whereas the English workers get less than half their usual earnings. For this reason any comparison of the prevalence of 'chronic bronchitis' in the Dutch and English populations is likely to be invalid.

There is no reason to doubt the validity of comparisons of the prevalence of chest symptoms, such as phlegm, cough, and wheezing, where the excess shown by the English workers is statistically significant.

Sputum.-Since it is always possible that the English complain about their symptoms more readily than the Dutch, the collection and examination of sputum was used to provide a more objective measure. It confirmed that the English workers had a higher prevalence of respiratory symptoms. In answer to the questionnaire, $30 \%$ of the English and $23 \%$ of the Dutch had said that they brought up phlegm first thing in the morning in the summer. But $36 \%$ of the English and only $19 \%$ of the Dutch workers actually produced phlegm on the test day. The sputum produced by the English workers was found to be both greater in volume and more purulent than that of the Dutch (Table 5).

Ventilatory Capacity.-The indirect maximum breathing capacity decreases with age and increases with sitting height. To make comparisons among the
English and Dutch card and blow room workers and spinners it was necessary to adjust the mean I.M.B.C. for each of the four groups to allow for differences in these two factors. For this purpose an analysis of covariance was carried out. This gave partial regression coefficients of -1.32 litres $/ \mathrm{min}$. per year for the regression of I.M.B.C. on age independent of sitting height, and +6.70 litres/min. per inch for the regression on sitting height independent of age. The overall difference between the adjusted means of the groups was found to be significant at the $\mathbf{0 . 0 0 1}$ level of confidence. Individual comparisons were then made between countries and between the two occupational groups within each country (Table 6). Dutch spinners have a significantly higher mean I.M.B.C. than either the Dutch card and blow room workers $(P<0.01)$ or the English spinners $(P<0.001)$. There are no significant differences between the English and Dutch card and blow room workers, nor between card and blow room workers and spinners in the English mills. When the means of all the English and of all the Dutch workers are adjusted for sitting height and plotted against age, the English have lower I.M.B.C.s for all age groups (Fig. 2).

In both countries the men with cough, phlegm or byssinosis have on the average lower I.M.B.C.s than those without symptoms (Fig. 3). Nevertheless, the much higher prevalence of respiratory symptoms among the English does not account entirely for the national differences in ventilatory capacity. Among the symptom-free, the Dutch have higher I.M.B.C.s than the English except in the 35-44 age group. When the card and blow room workers are divided into those with and without byssinosis the byssinotics 
TABLE 6

MEAN INDIRECT MAXIMUM BREATHING CAPACITY ADJUSTED FOR AGE AND SITTING HEIGHT IN ENGLISH AND DUTCH MALE COTTON WORKERS AGED 15-64 YEARS

\begin{tabular}{|c|c|c|c|c|c|}
\hline Group & $\begin{array}{l}\text { Number } \\
\text { of } \\
\text { Workers* }\end{array}$ & $\begin{array}{c}\text { Mean } \\
\text { Age } \\
\text { (years) }\end{array}$ & $\begin{array}{c}\text { Mean } \\
\text { Sitting Height } \\
\text { (in.) }\end{array}$ & $\begin{array}{l}\text { Unadjusted } \\
\text { Mean I.M.B.C. } \\
\text { (litres/min.) }\end{array}$ & $\underset{\text { Mean I.M.B.C. }}{\text { Adjusted }}$ \\
\hline $\begin{array}{l}\text { English card and blow room } \\
\text { English spinners } \\
\text { Dutch card and blow room } \\
\text { Dutch spinners }\end{array}$ & $\begin{array}{l}188 \\
194 \\
473 \\
503\end{array}$ & $\begin{array}{l}38 \\
45 \\
39 \\
38\end{array}$ & $\begin{array}{l}34 \cdot 4 \\
34 \cdot 5 \\
35 \cdot 0 \\
34 \cdot 9\end{array}$ & $\begin{array}{l}116 \cdot 9 \\
108 \cdot 2 \\
122 \cdot 9 \\
127 \cdot 8\end{array}$ & $\begin{array}{l}118 \cdot 1 \\
117 \cdot 5 \\
121 \cdot 1 \\
125 \cdot 4\end{array}$ \\
\hline
\end{tabular}

Significance levels for differences in adjusted mean I.M.B.C.s:-

English spinners vs. Dutch spinners

English card and blow room $y$. Dutch card and bow $P<0.001$

vs.

English card and blow room vs. English spinners $\quad P<0.0$

* One Dutch and six English workers have been excluded from the table because of incomplete data or absence from lung function tests.

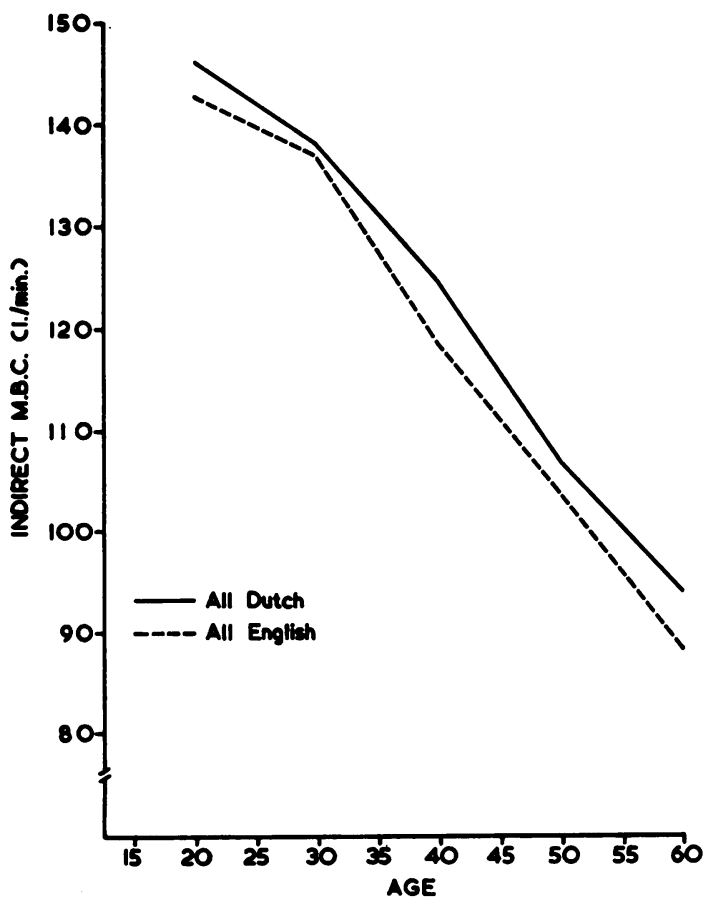

FIG. 2.- Indirect maximum breathing capacity adjusted for sitting height.

Mean I.M.B.C. $\underset{\text { English } 117 \cdot 8}{\text { Dutch } 123.1}\} \mathbf{P}<0.001$

in both countries have significantly lower I.M.B.C.s, but there is no clear indication from these figures that the disease is more disabling in one country than in the other (Table 7).

Reliability of Observations.-Before discussing possible explanations for the higher prevalence of chest symptoms and lower ventilatory capacities of the English cotton workers, we must consider the reliability of these observations. In this type of study, in which the results are based on the use of

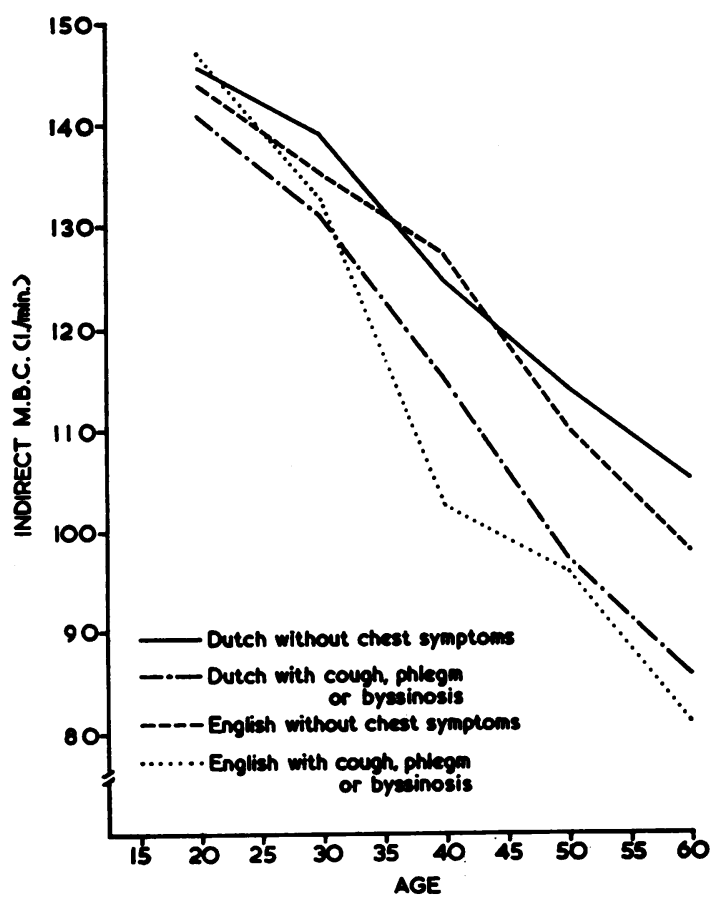

FIG. 3.-Indirect maximum breathing capacity adjusted for sitting height in workers with and without chest symptoms.

questionnaires and tests dependent on the subjects' co-operation, possible sources of error are introduced, particularly when there are several observers. We tried as far as we could to avoid such errors by using standardized questions and methods of testing. As the observers were allocated subjects randomly it was possible to get some measure of observer variability. In both countries there were some significant differences between observers, indicating that their standards of diagnosis and their testing techniques did vary. Nevertheless, all the English 
TABLE 7

MEAN INDIRECT MAXIMUM BREATHING CAPACITY ADJUSTED FOR AGE AND SITTING HEIGHT IN MALE CARD AND BLOWTHOUT BYSSINOSIS

\begin{tabular}{l|c|c}
\hline \multirow{2}{*}{} & \multicolumn{2}{|c}{$\begin{array}{c}\text { Adjusted Mean I.M.B.C. } \\
\text { (litres/min.) }\end{array}$} \\
\cline { 2 - 3 } & With Byssinosis & Without Byssinosis \\
\hline $\begin{array}{l}\text { English } \\
\text { Dutch }\end{array}$ & 107.5 & $120 \cdot 2$ \\
\hline
\end{tabular}

Significance levels for differences between workers with and without byssinosis:-

English P $<0.02$

Dutch $\mathbf{P}<0.01$.

observers found higher prevalences of persistent cough and phlegm and consistently lower mean I.M.B.C.s than the Dutch observers. At the same time the prevalence of byssinosis recorded by the various observers was much the same in both countries. Therefore, it seems likely that the differences between the two countries are real and not due to observer variation.

Working Environment.-Although methods of work and types of cotton spun in the English and Dutch mills were similar, mean dust concentrations were not (Table 8). While the English card rooms had, on the whole, higher concentrations of dust of all particle sizes (total dust), the concentrations of fine dust (particles less than $7 \mu$ ) were the same in both countries. For the spinning rooms the reverse

TABLE 8

MEAN DUST CONCENTRATIONS IN ENGLISH AND DUTCH $\operatorname{MILLS}\left(\mathrm{mg} . / \mathrm{m} .{ }^{3}\right)$

\begin{tabular}{|c|c|c|c|c|}
\hline \multirow[b]{2}{*}{ Workroom } & \multicolumn{2}{|c|}{ English Mills } & \multicolumn{2}{|c|}{ Dutch Mills } \\
\hline & $\begin{array}{l}\text { Total Dust } \\
\text { (mg./m. }\end{array}$ & $\begin{array}{l}\text { Fine Dust* } \\
\text { (mg./m. }\end{array}$ & $\underset{\text { (mg./m. }}{\text { Total Dust }}$ & $\begin{array}{c}\text { Fine Dust* } \\
\left.\text { (mg./m. }{ }^{3}\right)\end{array}$ \\
\hline $\begin{array}{l}\text { Card rooms } \\
\text { Spinning rooms }\end{array}$ & $\begin{array}{l}2.9 \\
0.4\end{array}$ & $\begin{array}{l}0.2 \\
0.03\end{array}$ & $\begin{array}{l}1.9 \\
2.6\end{array}$ & $\begin{array}{l}0.2 \\
0.1\end{array}$ \\
\hline
\end{tabular}

*Less than 7 microns.

was true, with the Dutch mills having more total and fine dust. The high dust concentrations in the Dutch spinning rooms are most likely to be produced by the travelling cleaners which blow dust off the machines into the air of the workroom. That there is no corresponding increase in the prevalence of byssinosis suggests that the dust is relatively inert.

Thus, differences in dust exposure do not seem to account for the excess of symptoms and lower ventilatory capacities among the English since this unfavourable picture was seen among the spinners as well as the card room workers.
Tobacco Smoking.-The importance of tobacco smoking in the aetiology of chronic respiratory disease has been repeatedly stressed (Fletcher, 1959; Higgins et al., 1959; Pemberton and Macleod, 1956; Ogilvie and Newell, 1957; Olsen and Gilson, 1960; Royal College of Physicians, 1962). Since smoking is so often associated with an increase in respiratory symptoms and a reduction in ventilatory capacity it was essential to examine smoking habits. There were fewer ex- and non-smokers among the Dutch, and their smokers consumed more tobacco than the English (Table 9). But $85 \%$ of the English smoked manufactured cigarettes, whereas $57 \%$ of the Dutch smoked a mixture of manufactured and hand-rolled cigarettes or the latter only (Table 10).

TABLE 9

PROPORTION OF SMOKERS AND AMOUNT SMOKED AMONG ENGLISH AND DUTCH COTTON WORKERS AGED 15-64 YEARS

\begin{tabular}{l|c|c}
\hline \multicolumn{1}{c|}{ Smoking Habits } & $\begin{array}{c}\text { English } \\
(\%)\end{array}$ & $\begin{array}{c}\text { Dutch } \\
(\%)\end{array}$ \\
\hline All workers & 100 & 100 \\
All cigarette smokers & 63 \\
Other smokers & 11 \\
Ex-smokers & 11 & 70 \\
Non-smokers* & 15 & 18 \\
\hline Smokers & 100 & 6 \\
$7-49$ g./week & 20 & 6 \\
$50-104$ g./week & 51 & 100 \\
$105-168$ g./week & 24 & 13 \\
$169+$ g./week & 5 & 51 \\
\hline
\end{tabular}

*Average consumption less than $7 \mathrm{~g}$./week (1 cigarette $=1 \mathrm{~g}$.).

TABLE 10

TYPE OF SMOKING

\begin{tabular}{l|c|c}
\hline \multicolumn{1}{c|}{ Type } & $\begin{array}{c}\text { English } \\
(\%)\end{array}$ & $\begin{array}{c}\text { Dutch } \\
(\%)\end{array}$ \\
\hline All smokers & $100 \cdot 0$ & $100 \cdot 0$ \\
Manufactured cigarettes & $\mathbf{8 5 \cdot 4}$ & $22 \cdot 5$ \\
Hand-rolled cigarettes & $0 \cdot 4$ & $18 \cdot 8$ \\
Mixed cigarettes & 0 & $38 \cdot 2$ \\
Other smokers & $14 \cdot 2$ & $20 \cdot 5$ \\
(pipes and cigars) & & \\
\hline
\end{tabular}

If the smokers of hand-rolled cigarettes had fewer symptoms than the smokers of manufactured cigarettes, this might explain the national difference in symptoms; but further examination showed that this was not so. After standardizing for age, occupation, and amount smoked, the ratio of observed cases to those expected was higher for the smokers of hand-rolled cigarettes than for any other group.

Atmospheric Pollution.-From the general appearance of the Lancashire towns with their grimy brick work and smoking chimneys, compared with the clean buildings and open spaces of Almelo, it may be inferred that the Lancashire cotton workers 
have been exposed to more air pollution than the Dutch.

To look more closely at the possible effects of air pollution, the English workers were divided into three groups: (1) those living in the south-east Lancashire conurbation; (2) those living in the towns on its fringe; and (3) those living in the towns outside the conurbation. Forty-three workers living in ill-defined areas were excluded. Indices of air pollution in the three areas were derived from measurements of smoke and sulphur dioxide taken in four towns during the winter months of 1960-61 and 1961-62 (Table 11). The air pollution in these three areas appears to be of a similar order. Nevertheless, these indices can serve only as a rough guide since there is a large amount of variation in recordings taken at different sites in the same town, and recordings were not always complete for the whole period.

To compare the prevalence of cough and phlegm in the three areas, standardized ratios were calculated to allow for differences in age, occupation, and smoking habits. There were no significant differences between these ratios (Table 11). Thus, for comparison with the Dutch, the English town dwellers have been grouped together.

The Dutch workers were divided into those living in the town of Almelo and those living in the country around the town. Fifty-five workers could not be classified in this way and were excluded. The townsfolk of Almelo show a higher prevalence of persistent cough and/or phlegm than the men living in the surrounding country.

If for each age group the English town dwellers are compared with the Dutch town and country dwellers, the pattern of prevalence is remarkably consistent. With the exception of the card and blow room workers aged 15-24, the English have the highest prevalence and the Dutch country dwellers the lowest, while the Dutch town dwellers occupy an intermediate position (Table 12).

In Holland, air pollution was measured from February 9 to April 1, 1963 at two sites in Almelo and in an adjacent rural area. The techniques used in the two countries were the same. The mean values of smoke and sulphur dioxide are compared with the mean values over the same period of time for the Lancashire towns for which pollution figures are available. The figures cover a very short period of observation, but they confirm the general impression that pollution in Lancashire is considerably higher than in Almelo, and higher in Almelo than in the surrounding rural areas. Prevalence of cough and phlegm, standardized to allow for differences in age, occupation, and smoking habits, appear to be related to the pollution levels of both smoke and sulphur dioxide (Table 13).

TABLE 11

RANGES OF AVERAGE MONTHLY CONCENTRATIONS OF AIR POLLUTANTS IN THE THREE LANCASHIRE AREAS* DURING THE WINTER MONTHS, OCTOBER TO MARCH, AND PREVALENCE OF PERSISTENT COUGH AND/OR PHLEGM STANDARDIZED FOR AGE, OCCUPATION, AND SMOKING HABITS

\begin{tabular}{|c|c|c|c|c|c|c|}
\hline & \multirow{3}{*}{ Area } & \multicolumn{4}{|c|}{ Air Pollution } & \multirow{3}{*}{$\begin{array}{c}\begin{array}{c}\text { Prevalence of } \\
\text { Cough and/or } \\
\text { Phlegm }\end{array} \\
\begin{array}{c}\text { Standardized } \\
\text { Ratios } \\
\text { (All English } \\
\text { Workers = 100) }\end{array}\end{array}$} \\
\hline & & \multicolumn{2}{|c|}{$\begin{array}{l}\text { Smoke } \\
\left(\mu \mathrm{g} . / \mathrm{m} .{ }^{3}\right)\end{array}$} & \multicolumn{2}{|c|}{$\begin{array}{l}\text { Sulphur Dioxide } \\
\left(\mu \mathrm{g} . / \mathrm{m}^{3}\right)\end{array}$} & \\
\hline & & $1960-61$ & $1961-62$ & $1960-61$ & 1961-62 & \\
\hline I & Swinton and Pendlebury & $246-527$ & $212-412$ & $303-629$ & $264-420$ & 99 \\
\hline II & $\begin{array}{l}\text { Bolton } \\
\text { Atherton }\end{array}$ & $\begin{array}{l}140-716 \\
340-648\end{array}$ & $\begin{array}{l}115-689 \\
221-650\end{array}$ & $\begin{array}{l}152-492 \\
286-471\end{array}$ & $\begin{array}{r}100-809 \\
90-728\end{array}$ & 91 \\
\hline & Horwich & $228-521$ & $189-499$ & 214-378 & $163-512$ & 122 \\
\hline
\end{tabular}

*For this period pollution measurements were available for only four towns.

TABLE 12

PREVALENCE OF PERSISTENT COUGH AND/OR PHLEGM IN MALE WORKERS IN ENGLISH AND DUTCH TOWNS AND DUTCH RURAL DISTRICTS

\begin{tabular}{|c|c|c|c|c|c|c|c|c|c|c|c|c|}
\hline \multirow[b]{3}{*}{ Age } & \multicolumn{6}{|c|}{ Card and Blow Room } & \multicolumn{6}{|c|}{ Spinning Room } \\
\hline & \multicolumn{2}{|c|}{ English Towns } & \multicolumn{2}{|c|}{ Dutch Town } & \multicolumn{2}{|c|}{ Dutch Rural } & \multicolumn{2}{|c|}{ English Towns } & \multicolumn{2}{|c|}{ Dutch Town } & \multicolumn{2}{|c|}{ Dutch Rural } \\
\hline & $\begin{array}{c}\text { No. of } \\
\text { Workers }\end{array}$ & $\begin{array}{c}\text { Prevalence } \\
(\%)\end{array}$ & \begin{tabular}{|c|} 
No. of \\
Workers
\end{tabular} & $\begin{array}{c}\text { Prevalence } \\
(\%)\end{array}$ & $\begin{array}{c}\text { No. of } \\
\text { Workers }\end{array}$ & $\begin{array}{c}\text { Prevalence } \\
(\%)\end{array}$ & $\begin{array}{c}\text { No. of } \\
\text { Workers }\end{array}$ & $\begin{array}{c}\text { Prevalence } \\
(\%)\end{array}$ & $\begin{array}{l}\text { No. of } \\
\text { Workers }\end{array}$ & $\begin{array}{c}\text { Prevalence } \\
(\%)\end{array}$ & $\begin{array}{c}\text { No. of } \\
\text { Workers }\end{array}$ & $\begin{array}{c}\text { Prevalence } \\
(\%)\end{array}$ \\
\hline $\begin{array}{c}15- \\
25- \\
35- \\
45- \\
55-64\end{array}$ & $\begin{array}{l}60 \\
27 \\
20 \\
41 \\
37\end{array}$ & \begin{tabular}{|l|}
$23 \cdot 3$ \\
33.3 \\
50.0 \\
58.5 \\
81.1
\end{tabular} & $\begin{array}{l}16 \\
61 \\
73 \\
64 \\
33\end{array}$ & $\begin{array}{r}6 \cdot 3 \\
22 \cdot 9 \\
24 \cdot 6 \\
32.9 \\
45 \cdot 5\end{array}$ & $\begin{array}{l}36 \\
75 \\
60 \\
22 \\
17\end{array}$ & $\begin{array}{l}16 \cdot 7 \\
17 \cdot 3 \\
20 \cdot 0 \\
22 \cdot 7 \\
29 \cdot 4\end{array}$ & $\begin{array}{l}37 \\
55 \\
21 \\
68 \\
53\end{array}$ & $\begin{array}{l}13.5 \\
40.0 \\
47.6 \\
41.2 \\
43.4\end{array}$ & $\begin{array}{l}46 \\
54 \\
58 \\
85 \\
28\end{array}$ & $\begin{array}{r}8 \cdot 7 \\
22 \cdot 3 \\
15 \cdot 5 \\
24 \cdot 7 \\
39 \cdot 4\end{array}$ & $\begin{array}{l}43 \\
74 \\
51 \\
39 \\
11\end{array}$ & $\begin{array}{r}4 \cdot 7 \\
6.9 \\
13.7 \\
20 \cdot 6 \\
18 \cdot 2\end{array}$ \\
\hline
\end{tabular}


TABLE 13

AIR POLLUTION FEBRUARY 9 TO APRIL 1, 1963* PREVALENCE OF COUGH AND/OR PHLEGM, STANDARDIZED FOR AGE, OCCUPATION, AND SMOKING HABITS, AND ADJUSTED INDIRECT MAXIMUM BREATHING CAPACITY IN LANCASHIRE TOWNS AND IN A DUTCH TOWN AND RURAL AREA

\begin{tabular}{|c|c|c|c|c|c|c|}
\hline \multirow{3}{*}{ Areas } & \multicolumn{4}{|c|}{ Air Pollution } & \multirow{3}{*}{\begin{tabular}{|c|}
$\begin{array}{c}\text { Prevalence of } \\
\text { Cough and/or Phlegm }\end{array}$ \\
Standardized Ratios $\dagger$ \\
\end{tabular}} & \multirow{3}{*}{$\begin{array}{c}\text { Adjusted } \\
\text { Mean } \\
\text { I.M.B.C. } \\
\text { (litres/min.) }\end{array}$} \\
\hline & \multicolumn{2}{|c|}{$\begin{array}{c}\text { Smoke } \\
\left(\mu \mathrm{g} . / \mathrm{m} .^{3}\right)\end{array}$} & \multicolumn{2}{|c|}{$\begin{array}{c}\text { Sulphur Dioxide } \\
\left(\mu \mathrm{g} . / \mathrm{m}^{3}\right)\end{array}$} & & \\
\hline & Mean & Range & Mean & Range & & \\
\hline $\begin{array}{l}\text { Lancashire towns* } \\
\text { Dutch town } \\
\text { Dutch rural area }\end{array}$ & $\begin{array}{r}320 \\
50 \\
41\end{array}$ & $\begin{array}{l}37-961 \\
12-132 \\
12-102\end{array}$ & $\begin{array}{l}279 \\
175 \\
105\end{array}$ & $\begin{array}{l}26-1743 \\
32-467 \\
25-293\end{array}$ & $\begin{array}{r}157 \\
87 \\
64\end{array}$ & $\begin{array}{l}119 \\
123 \\
124\end{array}$ \\
\hline
\end{tabular}

Significance levels for differences between standardized ratios:-

Lancashire towns vs. Dutch town $\quad \mathrm{P}<0.001$

*For this period atmospheric pollution figures in Lancashire were derived from measurements taken in seven towns where the majority of cotton workers lived.

+ All cotton workers $=100$.

\section{Discussion}

Vismans (1952) and Muller et al. (1962) have previously described byssinosis in Dutch cotton workers. Muller and his colleagues, who surveyed nine mills in Enschede which is near Almelo, suggested that it occurred there to a much lesser extent than in England. But the comparison was made with English mills spinning coarse grades of cotton where prevalences are known to be particularly high (Schilling, Hughes, Dingwall-Fordyce, and Gilson, 1955). In our survey, in which all the mills were spinning medium quality cotton, the prevalence of byssinosis was much the same in the two countries.

In both countries the prevalence in the spinning rooms was less than $2 \%$, and of those with byssinosis none was seriously affected. In the card and blow rooms the prevalence was about $15 \%$, which is considerably less than that found in the English coarse mills where about half the card room workers were affected (Roach and Schilling, 1960).

Byssinosis is a compensatable disease in England but not in the Netherlands. Yet during this survey seven Dutch card room workers with byssinosis were found to have very low I.M.B.C.s (less than 50 litres/min.), and eight were considered by their plant physician to need immediate transfer to other work. Before this survey at least three card room workers in these same mills were found by the plant physician to be disabled with byssinosis and were transferred.

In recent surveys, chronic bronchitis has been defined as persistent sputum with a history of at least one chest illness in the last three years involving absence from work for seven or more days (Higgins, 1957; Higgins and Cochran, 1958; Higgins et al., 1959; Olsen and Gilson, 1960). Any definition of bronchitis which includes illness causing lost time is likely to be unsuitable for certain types of epidemiological survey because it is seriously affected by a variety of industrial and economic factors (Fletcher, 1959). We now believe that valid comparisons of rates of bronchitis thus defined cannot be made between the English and Dutch because the latter receive much higher sickness benefits. We decided instead to focus our attention on the main respiratory symptoms associated with bronchitis, basing our comparisons on the prevalence of persistent cough and/or persistent phlegm. This produced the most striking difference between the two countries, with the English having higher prevalences at all ages (see Table 12).

The I.M.B.C. is also lower in the English than in the Dutch at all ages, with no indication of an increased divergence with age (Fig. 2). This is a surprising result if the English are being damaged by the effects of atmospheric pollution. Similarly, one would expect to see in the English, as one sees in the Dutch, that the divergence of I.M.B.C. between those with and without symptoms widens progressively with each increase in age (Fig. 3). A possible explanation is that during the last 15 years there has been a considerable contraction of the Lancashire cotton industry, which has encouraged the less fit in the older age groups to leave the mills.

The sputum survey, which is a relatively new epidemiological technique for studying non-specific respiratory disease, provided important additional evidence of the national difference.

Our results (see Fig. 3) support those of Fletcher, Elmes, Fairbairn, and Wood (1959), who found that patients with persistent cough and phlegm had lower I.M.B.C.s than those without these symptoms. In our survey the higher prevalence of symptoms among the English does not appear to account entirely for their lower ventilatory capacities. When the symptom-free in both countries are considered, the English still compare unfavourably with the Dutch.

There is no easy way of identifying the causes of 
chronic bronchitis, respiratory symptoms, and impaired ventilatory capacity. They are likely to be the product of inter-related genetic and environmental factors. But if we have shown a real difference between the English and Dutch cotton workers we must examine some of the factors that may be responsible for this difference.

In a comparative study of rural workers in Denmark and Great Britain, Olsen and Gilson (1960) explained the significantly lower prevalence of symptoms and higher I.M.B.C.s of the Danes by the fact that they had more non-smokers and fewer cigarette smokers than the British. Cigarette smoking is an important factor in chronic respiratory disease, and in a later paper will be shown to be so for our English and Dutch workers. Nevertheless differences in smoking habits do not appear to account for the higher prevalence of respiratory symptoms and lower ventilatory capacities of the English workers.

Many socio-economic factors, including occupation, are important in the aetiology of chronic respiratory disease (Reid, 1958). The harmful effect on the respiratory tract of industrial dusts is well known, but our results do not suggest that the dust hazard is greater in the English mills, since the prevalence of occupational respiratory disease was similar in both countries.

The social class gradient found in bronchitis morbidity and mortality rates in England and Wales cannot be explained by any one isolated factor and may be caused by the influence of a complex of social and environmental factors including diet, housing, medical care, and domestic overcrowding. It would be difficult to construct an adequate index to compare the socio-economic status of the cotton workers in the two countries, but the general impression is that the present social conditions of the English and Dutch workers are similar, although the Dutch worker may be better housed.

A positive association has been found between the density of population and some respiratory diseases. There is no doubt that population density is higher in the Lancashire towns than in Almelo and would provide increased opportunity for contact with respiratory infection. However, this factor is strongly associated with other environmental agents suspected of being injurious to health, such as domestic over-crowding and air pollution. In a study by Fairbairn and Reid (1958) the correlation of chronic bronchitis with population density was found to be insignificant after allowance had been made for the effects of domestic overcrowding and air pollution.

This brings us to the one factor that we have been unable to dismiss. There is no doubt that episodes of excessive air pollution produced by unusual climatic conditions have a harmful effect on the respiratory tract. This has been demonstrated by three major disasters in recent years: in the Meuse Valley in 1930 (Firket, 1936), in Donora in 1948 (Schrenk, Heimann, Clayton, Gafafer, and Wexler, 1949), and in London in 1952 (Logan, 1953).

Less is known about the long-term effects of sustained air pollution at lower concentrations. Investigations in England and Wales have shown an association between bronchitis mortality in county boroughs and the average recorded amount of sulphur dioxide (Pemberton and Goldberg, 1954), and between bronchitis mortality and indirect indices of air pollution such as domestic consumption of coal per acre, and per acre of built-up area (Daly, 1954, 1959).

Fairbairn and Reid (1958), in a study of postmen in the United Kingdom, used as an index of air pollution the results of a survey of visibility made in the winters of 1936-7 and 1937-8. They found that postmen working in areas of high pollution had more sickness absence from bronchitis than those in the less polluted areas.

Waller and Lawther (1957) and Carey, Phair, Shephard, and Thomson (1958) have shown that those already suffering from chronic bronchitis and emphysema are adversely affected by pollution.

Air pollution is one factor which could account for the difference between English and Dutch cotton workers in respiratory symptoms and ventilatory capacity. The difference in air pollution between the town and country areas of Almelo may also account for the excess of respiratory symptoms in the town dwellers.

Whereas previous studies have shown an association between air pollution and bronchitis mortality and morbidity, we have found an association with much earlier manifestations of respiratory disease, suggesting that pollution may initiate bronchitis and not merely aggravate it.

We are specially indebted to the management and workers of the cotton mills. They gave their wholehearted co-operation, and without their help this survey could not have been made.

We also thank the following: Dr. A. Marseille and Dr. M. T. Parker for the bacteriological examination of sputum; the local authorities in Lancashire, the Department of Scientific and Industrial Research, and the Research Organization for Applied Natural Sciences in the Netherlands for the pollution measurements-in particular we received advice and help from Dr. Brasser, Dr. Marjorie Clifton, Dr. P. J. Lawther and Mr. Waller; Dr. F. Guinee, Messrs. G. Koop, and A. J. van Leiden for assisting with the survey; Mr. Roy Pryce and many mill supervisors for their assistance with the dust sampling; Miss Sheila Farrow for helping to analyse 
data; and Mr. Andrew Colin of the London University Computer Unit for preliminary tabulations of data.

We have had helpful criticisms in preparing this paper from colleagues in the London School of Hygiene and Tropical Medicine, and from Dr. J. C. Gilson, Dr. P. J. Lawther, and Professor J. N. Morris.

We are grateful to the Medical Research Council for a grant to one of us (R.S.F.S.) without which this study could not have been undertaken.

\section{REFERENCES}

British Medical Journal (1962). 2, 781.

Carey, G. C. R., Phair, J. J., Shephard, R. J., and Thomson, M. L. (1958). Amer. industr. Hyg. Assoc. J., 19, 363.

Daly, C. (1954). Brit. med. J., 2, 687.

Elmes, P. C., Dutton, A. A. C., and Fletcher, C. M. (1959). Lancet, Elmes, P. C., 1241 .

Fairbairn, A. S., and Reid, D. D. (1958). Brit. J. prev. soc. Med., 12, 94

Firket, J.'(1936). Trans. Farad. Soc., 32, 1192.

Fletcher, C. M. (1959). Amer. Rev. resp. Dis., 80, 483. med. J., 2, 257.
, Elmes, Prirn, A. S., and Wood, C. H. (1959). Brit.
Goodman, N., Lane, R. E., and Rampling, S. B. (1953). Brit. med. J., $2,237$.

Higgins, I. T. T. (1957). Ibid., 2, 1198.

, and Cochran, J. B. (1958), Tubercle (Lond.), 39, 296.

Cochrane, A. L., Gilson, J. C., and Wood, C. H. (1959). Brit. J. industr. Med., 16, 255.

Lammers, B. (1962). Brit. med. J., 2, 663.

Logan, W. P. D. (1953). Lancet, 1336.

McKerrow, C. B., McDermott, M., Gilson, J. C., and Schilling, R. S. F. (1958). Brit. J. industr. Med., 15, 75 .

Muller, L., Vismans, J. B. M., and van Blommestein, E. J. (1962). Ned. T. Geneesk., 106, 421.

Ogilvie, A. G., and Newell, D. J. (1957). Chronic Bronchitis in Newcasile-upon-Tyne. Livingstone, Edinburgh.

Olsen, H. C., and Gilson, J. C. (1960). Brit. med. J., $1,450$.

Pemberton, J., and Goldberg, C. (1954). Ibid., 2, 567.

, and Macleod, K. I. E. (1956). Publ. Hlth Rep. (Wash.), 71, 1213. Reid, D. D. (1956). Proc. roy. Soc. Med., 49, 767.

Roach, S. A., and Schilling, R. S. F. (1960). Brit. J. industr. Med., 17, 1 .

Royal College of Physicians (1962). Smoking and Health. Pitman Medical Publishing Co., London.

Schilling, R. S. F. (1956). Lancet, 2, 261.

, Hughes, J. P. W., Dingwall-Fordyce, I, and Gilson, J. C. (1955). Hughes, J. P. W., Dingwall-Fordy

Schrent. industr. Med., 12, 217. Wexler, H. (1949). Air Pollution in Donora, Pa. Publ., Hlth Bull. (Wash.), No. 306.

Vismans, J. B. M. (1952). Ned. T. Geneesk, 96, 800.

Waller, R. E., and Lawther, P. J. (1957). Brit. med. J., 2, 1473. 